\title{
A Systematic Review on Graduate Mathematics Theses and Dissertations of State Universities and Colleges in Region I: A Basis for a Proposed Research Direction
}

\author{
Mark Angelo C. Reotutar \\ College of Teacher Education, University of Northern Philippines, Philippines
}

Received October 14, 2020; Revised November 18, 2020; Accepted December 11, 2020

\section{Cite This Paper in the following Citation Styles}

(a): [1] Mark Angelo C. Reotutar, "A Systematic Review on Graduate Mathematics Theses and Dissertations of State Universities and Colleges in Region I: A Basis for a Proposed Research Direction," Universal Journal of Educational Research, Vol. 8, No. 12A, pp. 7915-7927, 2020. DOI: 10.13189/ujer.2020.082580.

(b): Mark Angelo C. Reotutar (2020). A Systematic Review on Graduate Mathematics Theses and Dissertations of State Universities and Colleges in Region I: A Basis for a Proposed Research Direction. Universal Journal of Educational Research, 8(12A), 7915-7927. DOI: 10.13189/ujer.2020.082580.

Copyright $\mathrm{C} 2020$ by authors, all rights reserved. Authors agree that this article remains permanently open access under the terms of the Creative Commons Attribution License 4.0 International License

\begin{abstract}
Reviewing completed research studies aids research ecosphere to provide a conclusive and reliable bibliography; and it confirms a comprehensive generalization on the conducted researches along mathematics education. It aimed to systematically review the completed graduate mathematics education researches in SUCs in Region I to see the complete picture of the conducted researches in the region. Specifically, the researcher classified and characterized the graduate mathematics education researches in the region and identified the effect sizes of the researches. The researcher made used of the descriptive-quantitative method of research to systematically review the completed theses and dissertations in mathematics education. Specifically, a meta-analysis was done in some portions of the review. The following are the findings of the study: (1) the determinants of mathematics achievement of students have the greatest number of researches conducted by graduate mathematics students from the years 2007 to 2016. (2) Most of the conducted researches used correlation method of research and had a small to very small effect size index. (3) As consequence of the findings, a research mapping and a proposed research direction were crafted by the researcher for mathematics education future researchers. The results of the study tell that every university in the country should comprehensively choose research topics, monitor and guide their students who are enrolled in the graduate programs to avoid over saturation to research
\end{abstract}

topics especially in mathematics education. In the light of the findings and conclusions, the researcher recommended that the constructed proposed research mappings and directions should be used as guide in thinking what research area/s will be undertaken by future mathematics education researchers.

Keywords Instructional Materials, Pedagogies, Achievement, Research Mapping, Research Directions

\section{Introduction}

Mathematics education is necessary to improve the problem-solving and critical thinking skills of an individual. It can be demarcated as an integral part of a curriculum since it is one of the major areas needed to be developed by learners.

Refining education is one of the major trepidations of the current administration in the Philippines and lots of things should be considered to be competently accomplished such thing. We must elucidate and comprehend what we want to transform. This is why specialists and literati are making research and are creating new theories and concepts as their guides for such circumstances.

Research helps teachers to cognize what approaches in 
teaching that work and how these works. It should be future-oriented and premeditated to benefit learners rather than the researchers themselves. Policy makers should realize what short- and long-term implications are, and provide an ample justification and rationale for making judgments and actions. In the book of Austin [2], highpoints essentials of cultivating research studies to improve teaching and learning practice. According to her [2], research will find answers to specific challenges occurring inside a classroom. It reinforce an expert knowledge, skills and understanding. Research may also tie up with some data and systems of proficient support. It clarifies methods when doing curricular revisions. Teachers thru research may also lead them to be more effective and efficient.

Before students can graduate in any program or course, conducting a thesis, a dissertation, or a capstone project is often required to far-reaching their chosen degree programs. This is what the Commission on Higher Education (CHED) accentuated in the specific policies, standards, and guidelines (PSG) of numerous academic programs.

Based on the observations made by the researcher, students at the present time create and complete research studies just for the defiance of their degree program. They do not contemplate future outputs and concrete benefits of making research studies. They just go to the archives to makeover their studies with reference on the previous studies conducted without knowing and applying appropriate processes and principles in conducting research. The researcher also observed based on his readings that there are over saturated research topics and areas in terms of theses and dissertations conducted by graduate students.

On the one hand, in the Philippines, many studies conducted focused on the set of variables that could probably influence the mathematical performance or achievements of students. Researchers usually want to know what specific factors that promote achievement of students in mathematics. Although various factors have been well-thought-out, conjectured and investigated, there are still variations in the results. There are times that the results of one study complements the results of others, but many times results contradict each other. This is the reason why researchers seem to be hanging on a complete picture of academic achievement of students.

Based on the scenarios encountered, the researcher wants to determine the real status of mathematics research, especially in Region I and wants to know the potential factors influencing the mathematics performance of students through a research literature review coupled with a meta-analysis approach.

Lastly, the main focus of the study is to give a summary and synthesize the conducted theses and dissertations of graduate studies in SUCs, Region I along mathematics education. In addition, it further detects research areas of concerns that are over studied and what should be concentrated in conducting future research. Hence, this research is very useful, especially researchers in promoting and stimulating new knowledge and information about mathematics education.

In the conceptualization of this study, the researcher reviewed selected concepts and research that have bearing on the research.

Literature reviews are pervasive throughout various academic disciplines, and thus reviewers can adopt various approaches to effectively organize and write your literature review [12]. Moreover, they presented a summary of the various types of literature reviews created by the University of Southern California. The first type is the argumentative review that the researcher selectively examines literature in order to support or refute an argument, deeply imbedded assumption, or philosophical problem already established in the literature. The university reiterated that the purpose of this type is to develop a body of literature that establishes a contrarian viewpoint. The second is the integrative review which considered a form of research that reviews, critiques, and synthesizes representative literature on a topic in an integrated way such that new frameworks and perspectives on the topic are generated. The body of literature includes all studies that address related or identical hypotheses. If done well, integrative review meets the same standards as primary research in regard to clarity, rigor, and replication. Another type is the historical review which focused on examining research throughout a period of time, often starting with the first time an issue, concept, theory, phenomena emerged in the literature, then tracing its evolution within the scholarship of a discipline. The purpose of this type is to place research in a historical context to show familiarity with state-of-the-art developments and to identify the likely directions for future research. In the long run, the University of Southern California also presented a fourth type which is the methodological review which provides a framework of understanding at different levels (i.e. those of theory, substantive fields, research approaches and data collection and analysis techniques), it also enables researchers to draw on a wide variety of knowledge ranging from the conceptual level to practical documents for use in fieldwork in the areas of ontological and epistemological consideration, quantitative and qualitative integration, sampling, interviewing, data collection and data analysis, and lastly, it helps highlight many ethical issues which we should be aware of and consider as we go through our study.

The next is the systematic review which is the process used by the researcher in this study. It consists of an overview of existing evidence pertinent to a clearly formulated research question, which uses pre-specified and standardized methods to identify and critically appraise relevant research, and to collect, report, and 
analyse data from the studies that are included in the review. Last of all, theoretical review is an approach to concretely examine the corpus of theory that has been accumulated in regard to an issue, concept, theory, phenomena. The theoretical literature review helps establish what theories already exist, the relationships between them, to what degree the existing theories have been investigated, and to develop new hypotheses to be tested. Often this form is used to help establish a lack of appropriate theories or reveal that current theories are inadequate for explaining new or emerging research problems. The unit of analysis can focus on a theoretical concept or a whole theory or framework.

Likewise, doing a literature review may (1) tell what has and has not been probed; (2) detect data sources that other researchers may have used; (3) learn how others have defined and measured key concepts; (4) develop alternative research projects; (5) put works in perspectives; contribute to the field by moving research forward and let us see what came before, and what did and did not work for other researchers; demonstrate understanding and ability to critically evaluate research in the field; and provide evidence that may be used to support findings [1].

Systematic review is a literature review that is designated to locate, appraise and synthesize the best available evidence relating to a specific research question in order to provide informative and evidence-based answers [4].

There are actually three key activities when reviewing research systematically. (1) Reviewer should identify and describe relevant research studies through mapping the researches, (2) critically appraise research reports in a systematic manner, and (3) bring together the findings into a coherent statement known as synthesis [13]. On the other side, traditional literature reviews typically present research findings relating to a topic of interest. Researcher often summarizes what is known on a topic and tends to provide details on the studies which he/she considers without explaining the criteria he/she used in selection. The authors also emphasized that if the process of identifying and including studies is not explicit, it is not possible to assess the appropriateness of such decisions or whether they were applied in a consistent and rigorous manner. It is thus also not possible to interpret the meaning of the review findings.

Specifically, literature review for theses or dissertations has a unique item as an advent to scholarly works [21]. As stressed, doing literature review in scholar theses or dissertations is just like to publish studies articles; however, its shape is not totally the same [16]. In previous, there had been recurrent sprays of believers shouting for the express metamorphosis among scholar and skilled writers in accumulation to more prescribed three instructional applications for doctoral authors [5]; [15]; [19]; [21]. Hart [14] comprises an unsoiled justification of the necessity for the literature review in quest of instructional degrees and provides four important goals when doing a literature review in theses or dissertations. Researcher can amalgamate the thoughtful of graduate students-researchers in specific subject matter, authenticate scholar's laborious research keenness, substantiate future research, and comfy the graduate students into educated practice and propriety [6]. First, it synthesizes the expertise a scholar has on his/her unique challenge matter, it stands as a testimony to the scholar's rigorous studies dedication, it justifies destiny studies (inclusive of the thesis itself), and it welcomes the scholar into scholarly subculture and etiquette [6]. Lastly, shepherding literature review can promote an increase of the loads on the part of the reviewer in theses and dissertations since the evaluation may serve as an explanation for the originality of the graduate students' researches.

When Parris and Peachey [22] conducted a systematic literature review about servant leadership theory in organizational context, they found out that there is no agreement about an exact delineation of servant leadership. More so, the authors [22] also found out that the researchers of the empirical studies considered in the review were using varied measures just to discover more about servant leadership.

In the review done by Connolly, Boyle, MacArthur, Hainey \& Boyle [9] when they reviewed about computer games and serious games, they found out that playing computer games is totally linked to a wide range of perceptual, cognitive, behavioural, affective and motivational impacts and outcomes. These impacts and outcomes according to them [9] were knowledge acquisition comprehension and affective and motivational outcomes.

In the long run, Davies, Jindal-Snape, Collier, Digby, Hay \& Howe [10] revealed in their review about policy and professional literature on creative environments for learning in schools that a bulk of evidences support creative skills development for children. To have it, one should have a flexible use of space and time, use of available materials appropriately, let children work outside the classroom and use varied game-based approaches in teaching [10].

Moreover, Teodorovic [25] concluded in her review that learners' profile variables were considered to be the factors for students' achievement, following teachers' profile and methodologies.

The above research findings connote that reviewing literatures from previous studies may give a substantial bibliography about research topics. This is the reason why the researcher conducted this type of study since its focuses on the crafting a research map of the conducted theses and dissertations along mathematics education. 


\section{Statement of the Problem}

This study sought to answer the following questions:

1. What are the major areas of concerns of the conducted researches along mathematics education?

2. What are the characteristics of the researches in terms of year when research was conducted, educational level of the subjects, locale where researches were conducted, type of school where the subjects were taken, research design used, instrumentation and sample size?

3. What research mapping can be crafted in lieu of the literatures of the researches conducted?

4. As consequence of the review, what can be proposed as research directions for future researchers of mathematics education?

\section{Methodology}

This portion presents the research design used, sampling of the study, research instrument, data collection, and the data analysis of the research.

\subsection{Research Design}

The researcher made use of the descriptive-quantitative method of research to systematically review the completed theses and dissertations in mathematics education from the SUCs in Region I offering graduate education programs.

The descriptive method of research was used in the study since it involves collecting evidence by going over and inspecting completed researches in the graduate level. It also provides a precise explanation or picture of the status or features of the researches conducted.

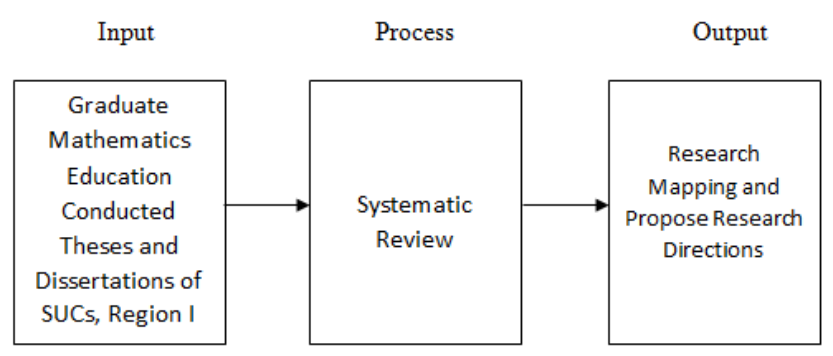

Figure 1. Research Flow

The above figure (1) shows that the researcher administered a systematic review on the conducted graduate mathematics education theses and dissertations of the different State universities and colleges in Region I to come up with a research mapping and to propose a research direction for future mathematics education researches.

\subsection{Sampling of the Study}

Ninety-two (92) completed theses and dissertations of graduate mathematics students from the state universities and colleges in Region 1 who took the following programs: Master of Arts in Mathematics Education (MAME), Master of Arts in Education major in Mathematics major in Mathematics (MAEd-Math), Master of Arts in Teaching Mathematics (MAT-Math), Master of Arts in Technology Education major in Mathematics (MATE-Math), Doctor of Philosophy in Mathematics Education (PhD-Mathematics Education) and Doctor in Education major in Mathematics (EdD-Mathematics) from 2007-2016. The distribution of the researches is presented in Table 1.

Table 1. Number of Theses and Dissertations in the Study

\begin{tabular}{|c|c|c|}
\hline $\begin{array}{c}\text { Conducted Researches in the region } \\
\text { along Graduate Mathematics Education }\end{array}$ & $\mathrm{n}$ & $\%$ \\
\hline Theses & 88 & 95.65 \\
\hline Dissertations & 4 & 4.35 \\
\hline Total & 92 & 100.00 \\
\hline
\end{tabular}

\subsection{Research Instrument}

The research instrument used in the study was a Research Summary Form which was validated by three experts along mathematics education. This form was crafted using a Microsoft Excel to facilitate the gathering of important data in all the selected researches under study. The column headers of the forms were the identified characteristics of the researches.

\subsection{Data Collection}

The completed researches were taken from all graduate studies libraries of the State, Universities and Colleges in Region I. The researcher categorized the studies into the following areas: determinants of mathematics achievement of students; effectiveness of mathematics teaching pedagogies; effectiveness of developed instructional materials in teaching mathematics; and other research areas conducted. All the 92 included researches from 2007-2016 were presented in the study. The researches were characterized as to year when the research was conducted, educational level of the subjects, locale where the research was conducted, type of school where the subjects were taken, research design used, research instrument/s used, and number of subjects used to be able to illustrate the researches thru a mapping. On the other hand, the category on other research areas conducted was further classified to identify the other research areas conducted by graduate mathematics researches. 


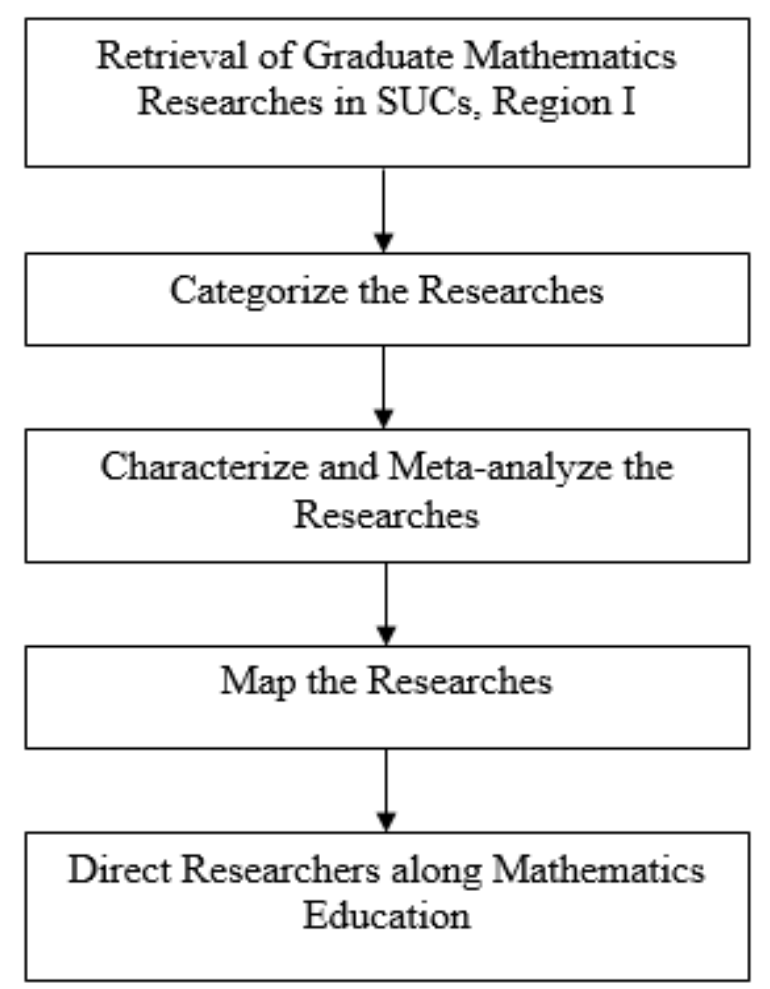

Figure 2. Research Flow

To organize the gathering of data needed in the study, the researcher identified the unit of analysis which was the completed theses and dissertations of graduate mathematics education of SUCs in Region I. After that, the researcher retrieved the lists of the available studies considering proper procedures and ethics.

Ninety-two (92) available studies from 2007-2016 were reviewed, extracted, coded and recorded through the use of a constructed and validated Research Summary Form.

After categorizing and characterizing the researches, the researcher mapped the researches to direct future graduate researchers on the needed research topics. Figure 2 presents the research flow of the study which served as guide of the researcher in doing this study.

\subsection{Data Analysis}

The researches were analyzed using frequency count and percentage to characterize the conducted researches. Since part of the study was to employ a meta-analysis, the researcher also identified the effect sizes per study.

\section{Results and Discussion}

This section presents the findings of the study.

\subsection{Major Research Areas Conducted in the Region}

Table 2 presents the distribution of the researches along the identified major areas. It can be gleaned from the table that 35 or $38.04 \%$ of the conducted researches in the State, Universities and Colleges in Region I were concentrated on determinants of mathematics achievement of students. This only means that graduate students in the region were more interested and really wanted to know the possible factors influencing the mathematics achievement of students as compared to the other identified research areas.

Table 2. Distribution of Researches along the Major Areas of Concern

\begin{tabular}{|c|c|c|}
\hline Major areas of concern included in the study & $f$ & $\%$ \\
\hline $\begin{array}{l}\text { a. Determinants of mathematics } \\
\text { achievement of students }\end{array}$ & 35 & 38.04 \\
\hline $\begin{array}{l}\text { b. Effectiveness of mathematics teaching } \\
\text { pedagogies }\end{array}$ & 13 & 14.13 \\
\hline $\begin{array}{l}\text { c. Effectiveness of developed instructional } \\
\text { materials in teaching } \\
\text { mathematics (IMs) }\end{array}$ & 10 & 10.87 \\
\hline d. Other areas in research conducted & 34 & 36.96 \\
\hline Total & 92 & 100.00 \\
\hline
\end{tabular}

Also, effectiveness of teaching pedagogies (13 or $14.13 \%)$ and IMs in teaching mathematics (10 or $10.87 \%$ ) were also prevalent among the conducted researches because of the programs considered in the study were all under education of which the main goal is to improve teaching pedagogies of teachers and to help the school and the curriculum to meet the quality of education.

Table 3 presents the distribution of the other researches included in the study. It can be gleaned from the table that 12 or 35.29 percent of the 34 researches were concentrated to resource materials development which signifies that researchers along mathematics education also showed interest in developing resource materials which can be used for teaching mathematics. This further implies that instructional resources in the teaching-learning process are needed for it will be more effective and efficient.

Table 3. Distribution of Researches along the Other Research Areas Conducted

\begin{tabular}{|c|c|c|}
\hline Classification of Other Research Areas & $f$ & $\%$ \\
\hline Resource Materials Development & 12 & 35.29 \\
\hline Implementation of Programs/Courses & 2 & 5.88 \\
\hline Pure Mathematics Research & 1 & 2.94 \\
\hline Meta-analysis Study & 1 & 2.94 \\
\hline $\begin{array}{c}\text { Mathematics Teachers' Preparedness, } \\
\text { Attitudes and Beliefs }\end{array}$ & 4 & 11.76 \\
\hline $\begin{array}{c}\text { Professional Licensure Examination } \\
\text { Professionals }\end{array}$ & 2 & 5.88 \\
\hline $\begin{array}{c}\text { Mathematics Skills of Non-Mathematics } \\
\text { Career }\end{array}$ & 1 & 2.94 \\
\hline $\begin{array}{c}\text { Preparedness of Students in their Chosen } \\
\text { Relevance of Mathematics in Other Field }\end{array}$ & 1 & 2.94 \\
\hline Business Entrepreneurial Research & 1 & 2.94 \\
\hline $\begin{array}{c}\text { Development of Intervention Programs in } \\
\text { Teaching and Learning Mathematics }\end{array}$ & 8 & 23.53 \\
\hline Total & 34 & 100.00 \\
\hline
\end{tabular}

In the article written by the Ministry of Education in 
7920 A Systematic Review on Graduate Mathematics Theses and Dissertations of State Universities and Colleges in Region I:

A Basis for a Proposed Research Direction

Guyana [20], they emphasized that teaching materials can support student learning and significantly increase students' achievement.

This will also add important structure to lesson planning and the delivery of instruction the mathematics class.

Surprisingly, it can also be observed that 8 or 23.53 percent researches were concentrated to the development of intervention programs in teaching and learning mathematics.

Lastly, 1 or 2.94 percent research found to the each of the following areas: pure mathematics researches, meta-analysis study, mathematics skills of non-mathematics professionals, and preparedness of students in their chosen career, relevance of mathematics in other field, and business entrepreneurial research. This signifies that these research areas are partly needed along education programs.

\subsection{Determinants of Mathematics Achievement of Students}

In the research conducted along the area- determinants of mathematics achievement of students, Table 4 shows that nine or 25.71 percent of the researches were produced in the mid of 2007-2016.

Table 4. Distribution of the Researches along Determinants of Mathematics Achievement of Students in the Identified Characteristics

\begin{tabular}{|c|c|c|}
\hline \multirow{2}{*}{ Characteristics } & $f$ & $\%$ \\
\hline & $\mathrm{n}=35$ & 100 \\
\hline \multicolumn{3}{|l|}{ Year when the research were conducted } \\
\hline $2007-2008$ & 7 & 20.00 \\
\hline $2009-2010$ & 6 & 17.14 \\
\hline 2011-2012 & 9 & 25.71 \\
\hline $2013-2014$ & 7 & 20.00 \\
\hline $2015-2016$ & 6 & 17.14 \\
\hline \multicolumn{3}{|l|}{ Educational level of the subjects } \\
\hline Elementary & 3 & 8.57 \\
\hline Secondary & 17 & 48.57 \\
\hline Tertiary & 15 & 42.86 \\
\hline \multicolumn{3}{|l|}{ Locale where the researches were conducted } \\
\hline Ilocos Norte & 5 & 14.29 \\
\hline Ilocos Sur & 28 & 80.00 \\
\hline La Union & 1 & 2.86 \\
\hline Others & 1 & 2.86 \\
\hline \multicolumn{3}{|l|}{ Type of school where the subjects were taken } \\
\hline Public & 29 & 82.86 \\
\hline Private & 5 & 14.29 \\
\hline \multicolumn{3}{|l|}{ Research design used } \\
\hline Descriptive- Correlation & 32 & 91.43 \\
\hline Descriptive- Correlation with comparative & 3 & 8.57 \\
\hline \multicolumn{3}{|l|}{ Research instruments used } \\
\hline Constructed information sheets and achievement test & 34 & 97.14 \\
\hline Constructed information sheets and achievement & \multirow{2}{*}{1} & \multirow{2}{*}{2.86} \\
\hline Test with retrieval of public documents & & \\
\hline \multicolumn{3}{|l|}{ Number of subjects used } \\
\hline $50-124$ & 8 & 22.86 \\
\hline $125-199$ & 7 & 20.00 \\
\hline $200-274$ & 10 & 28.57 \\
\hline $275-349$ & 9 & 25.71 \\
\hline $350-425$ & 1 & 2.86 \\
\hline
\end{tabular}


It can also be gleaned that researchers of the studies utilized secondary students as manifested in the frequency value of 17 or 48.57 percent.

This indicates that majority of graduate mathematics education students in the region who conducted determinants of mathematics achievement of students are secondary teachers. The table exhibits that most of the researches are located in the province of Ilocos Sur. It is observed that most of the researches used public schools as locale for the study.

Meanwhile, most of the researches used a descriptive-correlational research as their research design and used 200-274 number of subjects. This only implies that graduate mathematics researchers were aware about an adequate number of samples to be considered.

It showed support to the claim of Lyons [18] in his article about the tips to ensure reliable research data that sample sizes of 200 to 300 respondents provide an acceptable margin of error and fall before the point of diminishing returns.

\subsection{Effectiveness of Mathematics Teaching Pedagogies}

Table 5 revealed the characteristics of the graduate mathematics education researches along effectiveness of mathematics teaching pedagogies which are included in the meta-analysis study.

Table 5. Distribution of the Researches along Effectiveness of Mathematics Teaching Pedagogies in the Identified Characteristics

\begin{tabular}{|c|c|c|}
\hline \multirow{2}{*}{ Characteristics } & $f$ & $\%$ \\
\hline & $\mathrm{n}=13$ & 100 \\
\hline \multicolumn{3}{|l|}{ Year when the research was conducted } \\
\hline $2007-2008$ & 2 & 15.38 \\
\hline $2009-2010$ & 2 & 15.38 \\
\hline 2011-2012 & 1 & 7.69 \\
\hline 2013-2014 & 5 & 38.46 \\
\hline $2015-2016$ & 3 & 23.08 \\
\hline \multicolumn{3}{|l|}{ Educational level of the subjects } \\
\hline Elementary & 1 & 7.69 \\
\hline Secondary & 10 & 76.92 \\
\hline Tertiary & 2 & 15.38 \\
\hline \multicolumn{3}{|l|}{ Locale where the research was conducted } \\
\hline Ilocos Norte & - & - \\
\hline Ilocos Sur & 6 & 46.18 \\
\hline La Union & 6 & 46.18 \\
\hline Pangasinan & 1 & 7.69 \\
\hline \multicolumn{3}{|l|}{ Type of school where the subjects were taken } \\
\hline Public & 8 & 61.54 \\
\hline Private & 5 & 38.46 \\
\hline \multicolumn{3}{|l|}{ Research design } \\
\hline Experimental only & 12 & 92.31 \\
\hline Experimental coupled with correlation & 1 & 7.69 \\
\hline \multicolumn{3}{|l|}{ Research instrument } \\
\hline Constructed test instruments only & 10 & 76.92 \\
\hline Constructed test instruments with personal information sheet & 3 & 23.08 \\
\hline \multicolumn{3}{|l|}{ Number of respondents } \\
\hline $18-35$ & 3 & 23.08 \\
\hline $36-53$ & 2 & 15.38 \\
\hline $54-71$ & 3 & 23.08 \\
\hline $72-89$ & 3 & 23.08 \\
\hline $90-107$ & 1 & 7.69 \\
\hline $108-125$ & 1 & 7.69 \\
\hline
\end{tabular}


7922 A Systematic Review on Graduate Mathematics Theses and Dissertations of State Universities and Colleges in Region I:

A Basis for a Proposed Research Direction

The table also shows that, SUCs in the region produced 5 or $38.46 \%$ graduate mathematics education researches about the effectiveness of teaching pedagogies from 2013 to 2014 .

As seen from the table, great majority of the identified researches on the effectiveness of teaching interventions tested the secondary students while only 1 or $7.69 \%$ used elementary pupils as the respondents and 2 or $15.38 \%$ used the college students.

This implies that researchers of this set of studies were more interested in studying the effectiveness of pedagogies to the secondary students. This is attributed maybe to the fact that students in the secondary level need a lot of interventions in learning mathematics due to their difficulty in the subjects, and diversity of learners.

\subsection{Effectiveness of Developed Instructional Materials in Teaching Mathematics}

It is observed from the table (6) that after 2012, researches $(3$ or $30 \%)$ in the mathematics education graduate programs in SUCs in the region are focused on the effectiveness of developed instructional materials in teaching mathematics.

Table 6. Distribution of the Researches along Effectiveness of Developed IMs in Teaching Mathematics

\begin{tabular}{|c|c|c|}
\hline \multirow{2}{*}{ Characteristics } & $f$ & $\%$ \\
\hline & $\mathrm{n}=10$ & 100 \\
\hline \multicolumn{3}{|l|}{ Year when the research was conducted } \\
\hline $2007-2008$ & 2 & 20 \\
\hline 2009-2010 & 3 & 30 \\
\hline 2011-2012 & 2 & 20 \\
\hline $2013-2014$ & 1 & 10 \\
\hline $2015-2016$ & 2 & 20 \\
\hline \multicolumn{3}{|l|}{ Educational level of the subjects } \\
\hline Elementary & 2 & 20 \\
\hline Secondary & 6 & 60 \\
\hline Tertiary & 2 & 20 \\
\hline \multicolumn{3}{|l|}{ Locale where the research was conducted } \\
\hline Ilocos Sur & 5 & 50 \\
\hline La Union & 5 & 50 \\
\hline \multicolumn{3}{|l|}{ Type of school where the subjects were taken } \\
\hline Public & 8 & 80 \\
\hline Private & 2 & 20 \\
\hline \multicolumn{3}{|l|}{ Research design } \\
\hline Experimental only & 8 & 80 \\
\hline Experimental with correlation & 2 & 20 \\
\hline \multicolumn{3}{|l|}{ Research instrument } \\
\hline Constructed test instruments only & 8 & 80 \\
\hline Constructed test instruments with personal information sheet & 2 & 20 \\
\hline \multicolumn{3}{|l|}{ Number of respondents } \\
\hline $18-35$ & 3 & 30 \\
\hline $36-53$ & 1 & 10 \\
\hline $54-71$ & 2 & 20 \\
\hline $72-89$ & 1 & 10 \\
\hline $90-107$ & 2 & 20 \\
\hline $108-125$ & 1 & 10 \\
\hline
\end{tabular}


Meanwhile, $50 \%$ of these researches were conducted in the province of Ilocos Sur while the half was in the province of La Union.

Great majority ( 8 or $80 \%$ ) of these used pure experimental research while 2 or $20 \%$ used both experimental and correlation designs. Lastly, seven or $70 \%$ of the researches used less than 90 number of respondents.

\subsection{Other Research Areas Conducted}

Table 7. Distribution of the Researches along other research areas conducted

\begin{tabular}{|c|c|c|}
\hline \multirow{2}{*}{ Characteristics } & $f$ & $\%$ \\
\hline & $\mathrm{n}=34$ & 100 \\
\hline \multicolumn{3}{|l|}{$\begin{array}{l}\text { Year when the researches were } \\
\text { conducted }\end{array}$} \\
\hline $2007-2008$ & 8 & 23.53 \\
\hline $2009-2010$ & 5 & 14.71 \\
\hline $2011-2012$ & 10 & 29.41 \\
\hline 2013-2014 & 8 & 23.53 \\
\hline $2015-2016$ & 3 & 8.82 \\
\hline \multicolumn{3}{|l|}{$\begin{array}{l}\text { Locale where the researches were } \\
\text { conducted }\end{array}$} \\
\hline Ilocos Norte & 4 & 11.76 \\
\hline Ilocos Sur & 28 & 82.35 \\
\hline La Union & 1 & 2.94 \\
\hline Manila & 1 & 2.94 \\
\hline \multicolumn{3}{|l|}{ Research design used } \\
\hline Descriptive- Correlation & 32 & 94.12 \\
\hline $\begin{array}{l}\text { Descriptive- Correlation with } \\
\text { comparative }\end{array}$ & 2 & 5.88 \\
\hline
\end{tabular}

Table 7 shows the distribution of the other research areas conducted by the graduate mathematics students in Region I.

It can be observed from the table that great majority of the researches in this category were conducted in Ilocos Sur $(28$ or $82.35 \%)$. This would mean that researchers from 2007-2016 in Ilocos Sur do not only focused on one or two research topics but more. It means that there is a need to conduct research studies to generate new information not only focusing to one idea but should be in different perspectives. According to Unite for Sight [27], research must always be of high quality in order to produce knowledge that is applicable outside of the research setting. Furthermore, the results of the study may have implications for policy and future project implementation.

Lastly, most of the researches conducted casted-off descriptive-correlation method of research. This only signifies that student-researchers in the region often used this kind of research method. As defined by Cherry [8], correlational research is a preliminary way to gather information about a topic and is useful if researchers are unable to perform an experiment.

\subsection{Research Mapping of the Graduate Mathematics Researches in SUCs in Region I}

This research aimed to examine the status of the conducted graduate mathematics researches in different State Universities and Colleges (SUCs) in Region I from 2007 to 2016 to see what research agendas are over studied or under studied. 


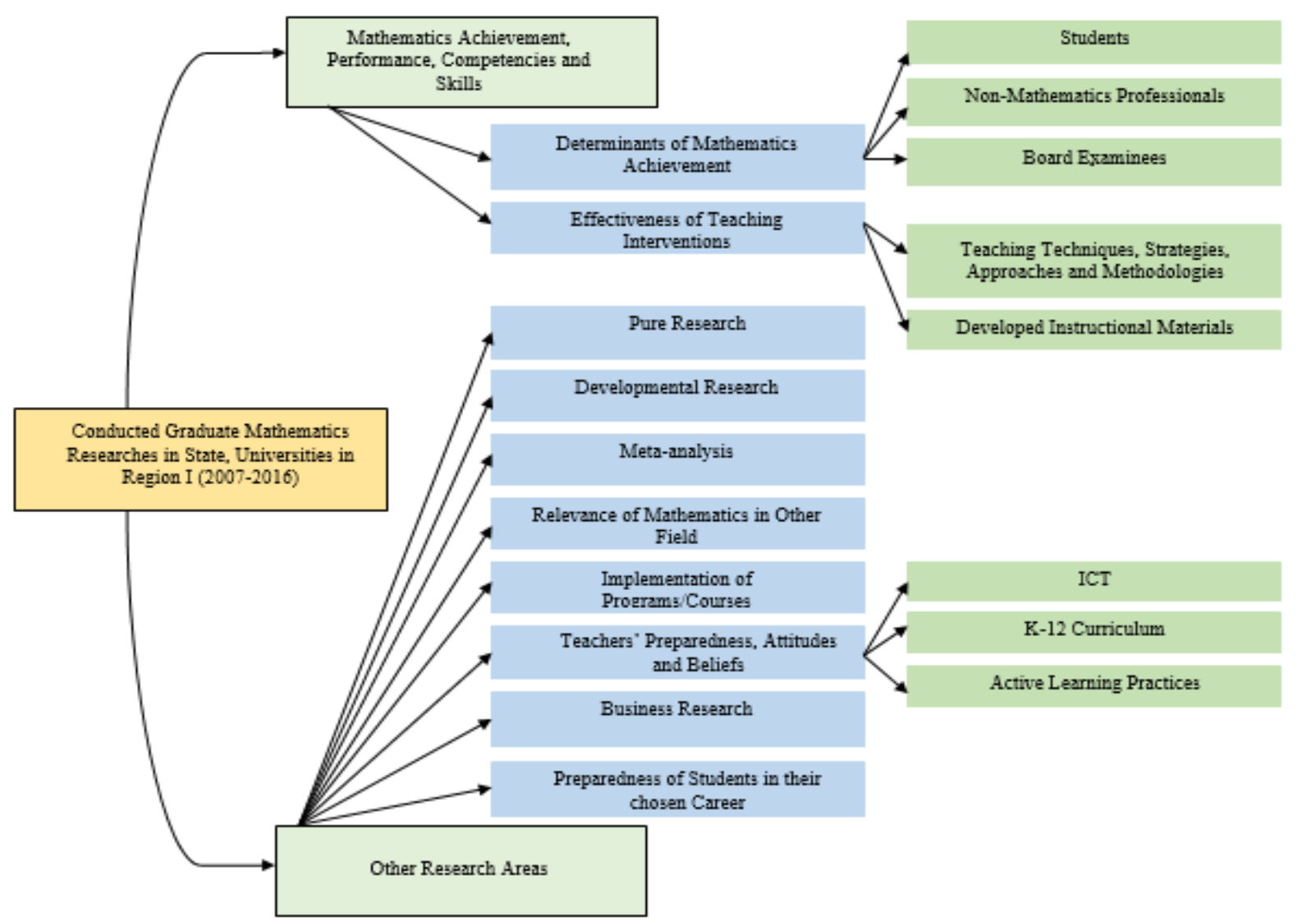

Figure 3. Research Mapping of Conducted Mathematics Graduate Researches in Region I (2007-2016)

Figure 3 also presents a research map of every research agenda conducted in the region along mathematics education.

The researcher classified the 92 researches into major areas: determinants of mathematics performance of students, effectiveness of mathematics teaching strategies, approaches and methodologies, effectiveness of developed instructional materials, and other areas.

Other research area involved resource materials development, implementation of programs/courses, pure mathematics research, meta-analysis study, mathematics skills of non-math professionals, preparedness of students in their chosen career, relevance of mathematics in other field, business entrepreneurial research, development of intervention programs in teaching and learning mathematics.

As to the characteristics of the graduate mathematics researches included in the meta-analysis, the following are some important highlights: 1) the educational level of subjects under study is more on public secondary level; 2) the researchers of these studies along determinants of mathematics achievement of students utilized more on descriptive-correlational research while on the effectiveness of teaching intervention, researchers all used experimental research; and 3) these set of researches took more than 200 number of respondents.

This is very helpful for researchers especially those who enjoy doing a meta-analysis study because it presents which researches can be studied and utilized. This also serves as a guide for students who are about to conduct a thesis or a dissertation.

\subsection{Discussion}

After a careful analysis on the findings, a proposed research direction was crafted which is presented on Table 8 . These research directions will benefit future researchers considering that higher education institutions are mandated to perform tri logic functions: instruction, research and extension.

The main goal of these directions is to guide future researchers to explore the hidden side of mathematics education. Mathematicians and mathematics educators need to generate new ideas, information or principles about mathematics by conjecturing or theorizing.

On the other hand, these are several learners who need simplified resource materials to be able to understand mathematics well.

Because of the challenges being faced in the new educational system, researchers should focus on studying new trends of teaching and learning through generating new designs on teaching pedagogies, and new educational models to have an effective mathematics curriculum.

Educators should think possible solutions by formulating new equations to eradicate poverty, to attain economic growth and development, and to increase 
passing rates on professional board examinations.

These research directions will benefit future researchers considering that higher education institutions are mandated to perform tri logic functions: Instruction, research and extension.

The main goal of these directions is to guide future researchers to explore the hidden side of mathematics education. Mathematicians and mathematics educators need to generate new ideas, information or principles about mathematics by conjecturing or theorizing.

On the other hand, these are several learners who need simplified resource materials to be able to understand mathematics well.

Because of the challenges being faced in the new educational system, researchers should focus on studying new trends of teaching and learning through generating new designs on teaching pedagogies, and new educational models to have an effective mathematics curriculum. Educators should think possible solutions by formulating new equations to eradicate poverty, to attain economic growth and development, and to increase passing rates on professional board examinations.

The results of the study tell that universities in the country should comprehensively choose research topics since it connotes to be one of the most important aspects of planning research and without a good research question, the results may be questionable [23]. It is important to note that when thinking a research topic, the researcher may consult research experts to make sure that the chosen topic is really the demand not only in an academe but also in the entire country. Brew [3] pointed out in her book on research and teaching that "Students need to be fully inducted into the culture and community of researchers. They need to develop knowledge of what it is to engage in the subject in a research-based way, to understand the key issues and debates in the subject area and know what researchers in the subject do, in general and specifically. They need to engage in activities which mirror the research processes that their teachers are engaged in. They need to learn methods and techniques used in research in the subject and have opportunities to practice such methods and techniques. This all implies that during their studies they should engage in building knowledge just like researchers." Lastly, graduate students should think critically and comprehensively when deciding their research topics.

Lastly, the researcher also noted one important limitation of this kind of study. One limitation is the unit of analysis used by the researcher. When conducting SLR, researchers should consider published researches to have a more reliable, valid and conclusive result.

Table 8. Research Directions for Graduate Mathematics Education

\begin{tabular}{|c|c|c|c|}
\hline \multicolumn{2}{|r|}{ Situationnaire (Highlight of Findings) } & Research Areas & Specific Research Topics \\
\hline \multicolumn{4}{|c|}{ To characterize the conducted graduate mathematics researches of SUCs, Region I } \\
\hline & \multirow{3}{*}{$\begin{array}{l}\text { Most researches conducted are } \\
\text { along } \quad \text { descriptive-correlational } \\
\text { design }\end{array}$} & Experimental research & $\begin{array}{l}\text { - Effectiveness of classroom interventions in } \\
\text { teaching mathematics } \\
\text { Eradication of poverty with the help of } \\
\text { mathematics numeracy }\end{array}$ \\
\hline & & Qualitative research & $\begin{array}{l}\text { - Mathematical equations to improve economics } \\
\text { - Making models for strategic teaching and } \\
\text { learning mathematics } \\
\text { - Making models on becoming effective } \\
\text { mathematics teacher and learner } \\
\text { Models on effectiveness of Mathematics } \\
\text { Curriculum } \\
\text { Designing an active learning practices }\end{array}$ \\
\hline & & Pure research & 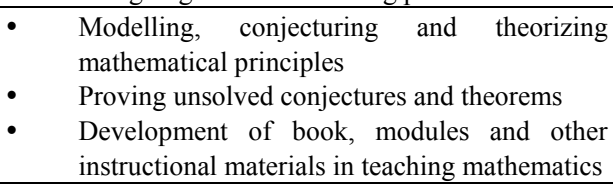 \\
\hline & $\begin{array}{l}\text { Instruments used are mostly } \\
\text { researcher-made tests }\end{array}$ & Test construction & $\begin{array}{ll}\text { - } & \text { Designing classroom assessment } \\
\text { - } & \text { Validation of researcher-made questionnaires } \\
\text { - } & \text { Standardization of test instruments } \\
\end{array}$ \\
\hline \multicolumn{4}{|c|}{ To determine the effect sizes of the identified research areas conducted } \\
\hline & $\begin{array}{l}\text { Most of the identified variables on } \\
\text { determinants of mathematics } \\
\text { achievement have trivial/very } \\
\text { small effect size index }\end{array}$ & $\begin{array}{l}\text { b. Adherence to require sample } \\
\text { size }\end{array}$ & Power analysis \\
\hline & \multirow{2}{*}{$\begin{array}{l}\text { All the experimental studies on } \\
\text { classroom interventions showed a } \\
\text { positive effect and demonstrated } \\
\text { effectiveness in learning } \\
\text { mathematics. }\end{array}$} & Experimental research & $\begin{array}{l}\text { Effectiveness of newly designed and high } \\
\text { quality teaching interventions in a mathematics } \\
\text { class }\end{array}$ \\
\hline & & d. Impact Study & $\begin{array}{l}\text { - } \begin{array}{l}\text { Delivery of the effective classroom } \\
\text { interventions in a numeracy extension programs }\end{array} \\
\end{array}$ \\
\hline
\end{tabular}




\section{Conclusions}

Based on the findings of the study, it is therefore concluded that researches along determinants of mathematics achievement of students and effectiveness of teaching interventions dominate graduate theses and dissertations in SUCs, Region I.

As a consequence of the systematics review made by the researcher a research mapping and the identified set of research directions can facilitate the formulation of graduate education research agenda.

To see the full image of the graduate mathematics education researches, future research studies should be conducted considering all available studies in the region.

Lastly, the crafted research directions should be used as guide in thinking what research area/s will be undertaken by future researches.

\section{Acknowledgments}

The author is grateful since he managed to accomplish this type of study and very much thankful to the State, Universities and Colleges (SUC) in Region I, Philippines for allowing the researcher to use all their reading resources especially the conducted theses and dissertations of their mathematics education graduate students.

\section{REFERENCES}

[1] American University. Literature review tutorial: Why do a lit review. 4400 Massachusetts Avenue, NW, Washington D.C. 20016. https://tinyurl.com/yyy67nx2 (accessed August 25, 2020)

[2] Austin, R. (2016). Researching Primary Education: What are the Benefits of Educational Research for Teachers? Learning Matters, First Edition. https://uk.sagepub.com/en-gb/asi/wh at-are-the-benefits-of-educational-research-for-teachers

[3] Brew, A. (2017). Research and teaching beyond the divide. Red Globe Press. https://books.google.com.ph/books?id=c Nelgiug7pEC\&printsec $=$ frontcover\&source $=\mathrm{gbs}$ atb $\# \mathrm{v}=$ on epage \&q\&f=false

[4] Boland, A., Cherry, G., \& Dickson, R. Doing a systematic review: A student's guide, $2^{\text {nd }}$ edition. Sage Publication. https://tinyurl.com/y2eaqgs8, 2017, pp. 8-9.

[5] Boote, D. N., \& Beile, P. Scholars before Researchers: On the centrality of the dissertation literature review in research preparation. Educational Researcher, 34(6), 3, 2005.

[6] Bruce, C. Interpreting the scope of their literature reviews: Significant differences in research students' concerns. New Library World, 102(4/5), 158. https://tinyurl.com/y3vfe49s (accessed September 4, 2020)

[7] Capate, R.N.A., \& Lapinid, M.R.C. Assessing the mathematics performance of grade 8 students as basis for enhancing instruction and aligning with $\mathrm{k}$ to 12 curriculum, 2015.

[8] Cherry, K. How correlational studies are used in psychology. https://tinyurl.com/y99ar5nx (accessed August 21, 2020).

[9] Thomas M. Connolly, Elizabeth A. Boyle, Ewan MacArthur, Thomas Hainey, James M. Boyle. A systematic literature review of empirical evidence on computer games and serious games. Computers \& Education, Volume 59, Issue 2. 2012. Pages 661-686. ISSN 0360-1315.https://doi.org/10.1016/j.c ompedu.2012.03.004

[10] Dan Davies, Divya Jindal-Snape, Chris Collier, Rebecca Digby, Penny Hay, Alan Howe. Creative learning environments in education-A systematic literature review. Thinking Skills and Creativity. Volume 8. 2013. Pages 80-91. ISSN 1871-1871. https://doi.org/10.1016/j.tsc.2012. 07.004

[11] Deuesh, S., \& Al Nasseri, D. Effectiveness of mathematics module in foundation programme in Majan College, 2014.

[12] Gorgas Library. How to conduct literature review: Types of literature reviews. https://tinyurl.com/y3lnnkxe (accessed August 13, 2020)

[13] Gough, D., Oliver, S., \& Thomas, J. An introduction to systematic reviews. Sage Publication. https://tinyurl.com/y5 4m447q, 2012.

[14] Hart C. Doing a literature review: Releasing the social science research imagination. London: SAGE Publications; 1998.

[15] Hüttner, J. The genre (s) of student writing: developing writing models. International Journal of Applied Linguistics, 18(2), 146-165, 2008.

[16] Kwan, B. S. C. The schematic structure of literature reviews in doctoral theses of applied linguistics. English for Specific Purposes, 25(1), 30-55, 2006.

[17] Lin, C.H., Lin, E.Z.F., Chen, Y.L., Chang, M., Wu, C.H. \& Yuan, S.M. Game-based remedial instruction mastery learning for upper primary school students. Educational Technology of Society, 16(2), 271-281, 2013.

[18] Lyons, K. Does your sample size matter? https://tinyurl.com/y4sk8ttz (accessed September 2, 2020)

[19] Maxwell, J. A. Literature reviews of, and for, educational research: A commentary on Boote and Beile's "scholars before researchers". Educational Researcher, 35(9), 4, 2006.

[20] Ministry of Education. The importance of learning materials in teaching. Gayuna. https://tinyurl.com/yy3ahbuw (accessed September 20, 2020)

[21] Okoli, C., Schabram, K. "A guide to conducting a systematic literature review of information systems research". https://tinyurl.com/y3n5kyb9. (accessed September 10, 2019)

[22] Parris, D.L., Peachey, J.W. A Systematic Literature Review of Servant Leadership Theory in Organizational Contexts. $J$ Bus Ethics 113, 377-393 (2013). https://doi.org/10.1007/s1 0551-012-1322-6

[23] Praharaj, S. K., \& Ameen, S. (2020). How to choose a research topic? 
[24] Rempel, H. G., \& Davidson, J. Providing information literacy instruction to graduate students through literature review workshops. Issues in Science and Technology Librarianship, 2, 2008.

[25] Teodorović, J. (2009). School effectiveness: Literature review. Зборник Института за педагошка истраживања Година 41. Број 1. Јун. Page 7-24. 10.2298/ZIPI0901007T
[26] Torres, P.L. \& Marriott, R.D.C. Handbook on research of collaborative learning using concept mapping. Hersey, New York, 2010.

[27] Unite for sight. Module 6: The importance of research. Unite for Sight International Headquarters United States of America. https://tinyurl.com/jcmhkbx (accessed September 17, 2019) 